\title{
Screening and characterization of new microsatellite markers in Fenneropenaeus penicillatus
}

\author{
J.B. Shangguan ${ }^{1,2}$, Z.B. Li ${ }^{1,2}$, Q.H. Li ${ }^{1,2}$, G. Dai ${ }^{1,2}$ and Y.F. Ning ${ }^{1,2}$ \\ ${ }^{1}$ Fisheries College, Jimei University, Xiamen, China \\ ${ }^{2}$ Fujian Provincial Key Laboratory of Marine Fishery Resources and \\ Eco-Environment, Xiamen, China \\ Corresponding author: Z.B. Li \\ E-mail: lizhongbao@jmu.edu.cn \\ Genet. Mol. Res. 13 (3): 6079-6082 (2014) \\ Received June 27, 2013 \\ Accepted December 10, 2013 \\ Published August 7, 2014 \\ DOI http://dx.doi.org/10.4238/2014.August.7.22
}

ABSTRACT. Fenneropenaeus penicillatus, with high protein and low fat, is a commercially important aquatic product in China. Microsatellite loci were developed according to the protocol of fast isolation by amplified fragment length polymorphism of sequences containing repeats. Eight new polymorphic microsatellite markers for $F$. penicillatus were identified, and 32 wild individuals were used to evaluate the degree of polymorphism of these markers. The polymorphism information content ranged from 0.2703 to 0.7598 , and the number of alleles per locus varied from 3 to 6 . The observed and expected heterozygosities were $0.1613-0.5556$ and $0.2347-0.7387$, respectively. No significant deviations from Hardy-Weinberg equilibrium $(\mathrm{P}>0.00625)$ were detected. These polymorphic microsatellite loci will be useful to study the genetic diversity and population structure of $F$. penicillatus.

Key words: Fenneropenaeus penicillatus; Polymorphic microsatellite loci; Magnetic bead enrichment 


\section{INTRODUCTION}

Fenneropenaeus penicillatus, generally called red tail shrimp by the Food and Agriculture Organization, is widely distributed in the India and Indonesia coastal waters, especially in the East China Sea and South China Sea. It became a major breeding object in Guangdong, Taiwan, and the south of Fujian of China for its delicious taste, rich nutrition, and rapid growth (Zhang et al., 2010). However, in recent years, due to the destruction of habitats, spawning, and other natural environments, as well as the overfishing of wild resources and continuous outbreak of popular shrimp diseases, the aquaculture and resource capacity of $F$. penicillatus both sharply declined. In 2005, F . penicillatus was included in the Red List by the Chinese government as an endangered species (Wang and Xie, 2009). Protecting and rejuvenating $F$. penicillatus resources are imperative. Currently, microsatellite molecular markers are widely and expertly applied to the research of many species for genetic conservation. Polymorphic microsatellite loci of $F$. penicillatus were developed (Cao et al., 2012). Nevertheless, information about the genetic background of $F$. penicillatus remains limited (Voloch et al., 2005). Therefore, we developed eight novel polymorphic microsatellite loci that could contribute to protect the natural resources and promote the development of aquaculture for $F$. penicillatus.

\section{MATERIAL AND METHODS}

The microsatellite makers were developed using a modified fast isolation by amplified fragment length polymorphism of sequences containing repeat protocol (Zane et al., 2002). Genomic DNA was extracted from the muscle of a single wild $F$. penicillatus that was captured in Beihai, China, by using a modified cetyltrimethylammonium bromide extraction. High-quality genomic DNA $(20 \mu \mathrm{L} 100 \mathrm{ng} / \mu \mathrm{L})$ was digested with $1 \mu \mathrm{L}$ FastDigest Tru1I (Fermentas, Canada) restriction enzyme in a $25-\mu \mathrm{L}$ volume for $10 \mathrm{~min}$ at $65^{\circ} \mathrm{C}$. The digested fragments, ranging from 400 to $1200 \mathrm{bp}$, were ligated to $\mathrm{Mse}$ I adapter1 (5'-ACGATGAGTCCTGAG-3')/MseI adapter2 (5'-TACTCAGGACTCAT-3') by T4 DNA ligase at $22^{\circ} \mathrm{C}$ for $10 \mathrm{~h}$. The digestion-ligation fragments were denatured at $95^{\circ} \mathrm{C}$ for $10 \mathrm{~min}$ and were immediately hybridized to the biotinylated oligonucleotide probes (CT)15 and (GT) 15 at $61^{\circ} \mathrm{C}$ for $1 \mathrm{~h}$. Afterwards, the fragments containing microsatellite repeats were captured and gathered by streptavidin-coated magnetic sphere particles (Promega, USA), and the noncaptured and loose DNA fragments were washed away. The recovered DNA fragments were amplified using $M s e I$ adapterl. After purification by GenClean Cycle Pure Kit (Omega Bio-Tek) to remove the extra adapters and dNTPs, the purified products $(4 \mu \mathrm{L})$ were ligated to $1 \mu \mathrm{L}$ pMD19-T (TaKaRa, Japan) at $16^{\circ} \mathrm{C}$ for $3 \mathrm{~h}$ and then were transformed into Escherichia coli DH5 $\alpha$ (TIANGEN, China) for further selection on ampicillin plates. The positive clones were amplified by M13 general primers, and the polymerase chain reaction (PCR) products were separated on $1 \%$ agarose gels. One hundred fragments that ranged from 500 to $1000 \mathrm{bp}$ were selected to sequence by the Majorbio Company (Shanghai, China).

Ninety-five fragments were successfully sequenced, and 70 microsatellite sequences meeting the requirements were hunted by SSRhunter1.3. Thirty-eight pairs of microsatellite amplification primers were designed by Primer Premier5.0.32. Genomic DNA samples that were extracted from 32 wild individuals from Beihai, China, were used to test the polymorphism of these 38 microsatellite markers. The PCR amplification was in a volume of $10 \mu \mathrm{L}$ and was performed on a gradient thermal cycler (Bio-Rad). The PCR protocol was designed as 
follows: denaturation for $5 \mathrm{~min}$ at $94^{\circ} \mathrm{C} ; 30$ cycles of $45 \mathrm{~s}$ at $94^{\circ} \mathrm{C}, 45 \mathrm{~s}$ at annealing temperature (Table 1), and $1 \mathrm{~min}$ at $72^{\circ} \mathrm{C}$; a final extension at $72^{\circ} \mathrm{C}$ for $10 \mathrm{~min}$; and storage at $4^{\circ} \mathrm{C}$. The amplified products were separated on polyacrylamide gels in a Sequi-Gen Sequencing Cell (Bio-Rad) and were visualized by silver staining. Finally, the important genetic information and index of the 8 polymorphic microsatellite loci were calculated by POPGENE 32 (version 1.32) (Yeh et al., 2000) and CERVUS 3.0 (version 3.0) softwares.

\begin{tabular}{|c|c|c|c|c|c|c|c|c|c|c|}
\hline $\begin{array}{l}\text { GenBank } \\
\text { accession No. }\end{array}$ & $\begin{array}{l}\text { Locus } \\
\text { ID }\end{array}$ & Primer sequences (5'-3') & $\begin{array}{l}\mathrm{Ta} \\
\left({ }^{\circ} \mathrm{C}\right)\end{array}$ & Repeat motif & $\begin{array}{l}\text { Allele size } \\
\quad(\mathrm{bp})\end{array}$ & $N_{\mathrm{A}}$ & PIC & $H_{\mathrm{o}}$ & $H_{\mathrm{E}}$ & P-HWE \\
\hline KF055840 & FP1-13 & $\begin{array}{l}\text { F: AGGGCTCTCTCCTCAGGCAAG } \\
\text { R: TCACTGGGATTCTCAGCGACG }\end{array}$ & 60 & $(\mathrm{CA})_{11}$ & $110-120$ & 3 & 0.4057 & 0.3125 & 0.5059 & 0.0290 \\
\hline KF055841 & FP2-13 & $\begin{array}{l}\text { F: CCTCCCTACCAACCACAGTC } \\
\text { R: TATCATAACGCAGAGCAAAA }\end{array}$ & 60 & $(\mathrm{CATCC})_{3}$ & $170-190$ & 4 & 0.3643 & 0.3226 & 0.3522 & 0.7230 \\
\hline KF055842 & FP-14 & $\begin{array}{l}\text { F: CTCTCACTCCGAGATGGG } \\
\text { R: GCTGGTTGGTGTTGCTTT }\end{array}$ & 43 & $\begin{array}{l}(\mathrm{CAC})_{3} \mathrm{CAT}\left[(\mathrm{CAC})_{36}\right. \\
\left.(\mathrm{CTT})_{2}\right]_{3}(\mathrm{CAC})\end{array}$ & $260-340$ & 4 & 0.5644 & 0.3704 & 0.5178 & 0.3612 \\
\hline KF055843 & FP-15 & $\begin{array}{l}\text { F: TGAGTGACTGCTTGGTAA } \\
\text { R: GAGAGGATGAGAGGGTAT }\end{array}$ & 55 & $\mathrm{~T}_{15}$ & $220-245$ & 4 & 0.2812 & 0.1613 & 0.2555 & 0.0194 \\
\hline KF055844 & FP-25 & $\begin{array}{l}\text { F: CCACCAACTCTCACACC } \\
\text { R: CATAGCACTCGGGCATC }\end{array}$ & 55 & $(\mathrm{TTC})_{3} \mathrm{~N}(\mathrm{TC})_{8}$ & $190-210$ & 4 & 0.4268 & 0.3448 & 0.3609 & 0.7327 \\
\hline KF055845 & FP-40 & $\begin{array}{l}\text { F: TTCCCTCGCCCCCCCTTTC } \\
\text { R: CGCCCCTCTGGCTTGCTTT }\end{array}$ & 60 & $(\mathrm{AG})_{14}$ & $185-240$ & 6 & 0.7598 & 0.5556 & 0.7387 & 0.0460 \\
\hline KF055846 & FP-43 & $\begin{array}{l}\text { F: TAAGGAAGGGGAGGGAAG } \\
\text { R: ACCTGCCTGCCTATCTGT }\end{array}$ & 56 & $(\mathrm{GA})_{4} \mathrm{~N}(\mathrm{AAAG})_{3}$ & $125-135$ & 5 & 0.2703 & 0.2581 & 0.2347 & 0.9966 \\
\hline KF055847 & FP-67 & $\begin{array}{l}\text { F: AGAGAGAGTGAAAGACAAGGAATA } \\
\text { R: TCAAGATGAACAATGTGATAATAA }\end{array}$ & 55 & $(\mathrm{AAAG})_{3}$ & $128-150$ & 4 & 0.3080 & 0.2812 & 0.3262 & 0.0075 \\
\hline
\end{tabular}

$\mathrm{Ta}=$ annealing temperature $N_{\mathrm{A}}=$ number of polymorphic alleles per locus; PIC = polymorphism information content; $H_{\mathrm{O}}=$ observed heterozygosity; $H_{\mathrm{E}}=$ expected heterozygosity; P-HWE = P values for the Hardy-Weinberg expectation test (adjusted $\mathrm{P}=0.00625$ ).

\section{RESULTS AND DISCUSSION}

Four monomorphic microsatellite loci and eight polymorphic microsatellite loci were screened, and the characterization of the eight loci is presented in Table 1. The number of alleles per locus ranged from 3 to 6 , and the polymorphism information content varied from 0.2703 to 0.7598 by CERVUS3.0. The observed and expected heterozygosities were 0.16130.5556 and $0.2347-0.7387$ by POPGENE 32 , respectively. No loci significantly deviated from Hardy-Weinberg equilibrium, and there was no genotypic linkage disequilibrium in the tested population after Bonferroni's correction (adjusted $\mathrm{P}=0.00625$ ).

The eight novel polymorphic microsatellite loci presented here could provide useful and important information for further population studies and cultivation in $F$. penicillatus.

\section{ACKNOWLEDGMENTS}

Research supported by the National Natural Science Foundation of China (\#31272668), the Natural Science Foundation of Fujian Province (\#2010J01213), the Program of Fujian Provincial Department of Science and Technology (\#JK2010034), and the Program for New Century Excellent Talents in Fujian Province University and the Foundation for Innovative Research Team of Jimei University, China (\#2010A004). 


\section{REFERENCES}

Cao YY, Li ZB, Zhang GL, Chen XJ, et al. (2012). Isolation and characterization of ten microsatellite markers of Fenneropenaeus penicillatus. Conserv. Genet. Resour. 4: 261-263.

Voloch CM, Freire PR and Russo CA (2005). Molecular phylogeny of penaeid shrimps inferred from two mitochondrial markers. Genet. Mol. Res. 4: 668-674.

Wang S and Xie Y (2009). China Species Red List. 1st Vol. China Higher Education Press, Beijing.

Yeh FC, Yang R, Boyle TJ and Ye Z (2000). PopGene32, Microsoft Windows-Based Freeware for Population Genetic Analysis. Version 1.32. Molecular Biology and Biotechnology Centre. University of Alberta, Edmonton.

Zane L, Bargelloni L and Patarnello T (2002). Strategies for microsatellite isolation: a review. Mol. Ecol. 11: 1-16.

Zhang GL, Li ZB, Wang ZL, Lin XY, et al. (2010). Study status and perspective of Fenneropenaeus penicillatus. Mod. Fish. Inform. 2010: 7-10. 